\title{
TRANSPARENCY OF THE DECISION-MAKING PROCESS DURING THE CORONAVIRUS PANDEMIC1
}

\author{
TRANSPARENTA PROCESULUI DECISIONAL \\ ÎN PERIOADA PANDEMIEI DE CORONAVIRUS
}

DOI: https://doi.org/10.53783/18572294.21.186.06

CZU: 352/354:316.42

Irina CEACÎR, Doctor of Political Sciences, Institute of Legal, Political and Sociological Research i.a.ceacir@gmail.com

Ecaterina ȘUBINA, student, Hague University of Applied Sciences rina.shubina2001@gmail.com

\section{Rezumat}

Anul 2020 este un an al schimbărilor globale. Răspândirea virusului COVID-19 a fost un impuls pentru transformare. Intregul glob se confruntă cu impedimente greu de anticipat, dar care pune în pericol viața oamenilor. Acest articol se referă la transparența procesului decizional în perioada pandemiei. De asemenea, se explică problemele de comunicare ce pot apărea în situații complicate între administrația publică și cetățean. Atât autoritățile Uniunii Europene, în general, cât și cele ale Republicii Moldova, în special, întâmpină probleme sociale care trebuie rezolvate într-o perioadă foarte scurtă. Multe decizii trebuie luate cu promptitudine și viziune pe termen lung. Este important ca acest proces să nu afecteze calitatea serviciilor publice furnizate și să nu aducă atingere drepturilor cetățenilor. Astfel, procesul decizional trebuie să fie transparent și accesibil cetățenilor.

Cuvinte-cheie: pandemie, COVID-19, transparență, serviciu public, cetățean, administrație publică, stat, guvernare, transformare, comunicare, proces decizional, autorități, Uniunea Europeană

\section{Summary}

2020 is a year of global change. The spread of the COVID-19 virus was an impetus for transformation. The entire globe confronts impediments hard-to-anticipate, but who endangers people's life. This article refers to the transparency of the decision-making process in the pandemic period. Also, it is explained the communication problems that can appear in complicated situations between the public administration and the citizen. Both the authorities of the European Union, in general, and of the Republic of Moldova, in particular, encounter social problems, which must be resolved in a very short period. Many decisions must be made promptly and unforeseen. It is important that this process does not affect the quality of public services provided and does not infringe on the rights of citizens. Thus, the decision-making process must be transparent and accessible to citizens.

Keywords: pandemic, COVID-19, transparency, public service, citizen, public administration, state, government, transformation, communication, decision-making, authorities, European Union

The transparency of the decision-making process is manifested by providing in an open, clear and appropriate form to the situation by the rulers and members of the public administration of information of public interest on the governing act

\footnotetext{
${ }^{1}$ Articolul a fost elaborat în cadrul expresiei de interes 20.70086.20/COV „Politici bazate pe dovezi în perioada pandemiei COVID-19: perspectivele aplicării practice a conceptelor „Guvernării deschise” și „Ştiinței deschise” în Republica Moldova” finanțat prin intermediul ANCD
} 
and any activity that may affect the ordinary citizen. Nothing should be hidden or undeclared. The need for citizen participation in all stages of decision-making is the only way to streamline the entire decision-making process. The interrelationship between public administration and civil society has a special role, which should allow the citizen to get involved in the decision-making process without any impediments because the changes that are taking place lately in the sphere of public administration require more and more citizen and community involvement. The closer the collaboration between the public administration and the community, the more it increases the citizen's trust in the act of governing, and vice versa, the harder it is to get involved, the less likely the citizen to support the reforms that want to be implemented. The period of the coronavirus pandemic is a difficult one and full of obstacles, but they should not allow certain errors that would be to the detriment of the citizen. With small steps, the process must be reorganized within the public administration, so that there are no gaps in terms of informing the citizen of everything that can affect him in the short or long term.

The principle of transparency is closely linked to the right to information, to the administration of public affairs, as well as to the right to petition, a fact established both at national and international levels. The Universal Declaration of Human Rights provides in art.19 the right of the person to receive information by any means, and art. 21 establishes the right to take part in the conduct of public affairs of their country, consequently, all the states of the world, which are parts of the Universal Declaration of Human Rights, accept its provisions and transpose them into their domestic law. At national level, the Republic of Moldova enshrines the principle of transparency in the decision-making process in the Constitution of the Republic of Moldova, in art. 34 "The right to information", which provides the right of the person to have access to any information of public interest and the obligation of state authorities to ensure the correct information of citizens on public affairs and matters of personal interest, as well as the obligation to protect this right of the citizen [1]. In addition to the constitutional provisions, there are several other legislative acts that come to regulate, in a more precise way, the implementation of the principle of transparency in the decision-making process [2].

Law no. 239 of 13.11.2008 on transparency in the decision-making process establishes the rules applicable to ensure transparency in the decision-making process within the central and local public administration authorities, other public authorities and it regulates their relations with citizens, associations established by the law and other stakeholders interested to participate in the decision-making process. Likewise, the principles of transparency of the decision-making process are mentioned: informing, in an established way, the citizens, the associations established by the law, other interested parties about the initiation of the elaboration of decisions and the public consultation on the project decisions; ensuring equal opportunities for the participation of citizens, associations established by the law, other stakeholders in the decision-making process. Citizens, associations, other 
stakeholders have the rights: to participate in any stage of the decision-making process; request and obtain information on the decision-making process, including receiving project decisions accompanied by related materials; to propose to the public authorities the initiation of the elaboration and adoption of decisions; to present to the public authorities' recommendations regarding the project decisions under discussion. In the same context, public authorities are obliged to: take the necessary measures to ensure the participation of citizens, associations established by the law, other stakeholders in the decision-making process, including by disseminating information on annual programs (plans) for activity by placing them on the official website of the public authority, by displaying them at its headquarters in a space accessible to the public and/or by broadcasting them in the central or local media, as the case may be; informing, in an established way, on the organization of the decision-making process; institutionalization of cooperation and partnership with the society; receiving and examining the recommendations of citizens, associations established by the law, other stakeholder to use them in project decisions; consultation of the views of all interested parties in the examination of project decisions [3].

Thus, the legislative framework stipulates very clearly what the ways of informing the general public in the decision-making process should be. If all these aspects are taken into account, or not, the citizen has to check and to ask when it is not offered. The citizen must be involved, informed and kept up to date with everything that is happening. A relevant issue, which should be highlighted, is the way of information in public consultations. Thus, informing on the decision-making process is made through general information, for an indefinite general public, and through targeted information, for defined stakeholders, or other stakeholders who have requested the information in writing. General informing is mandatory in case of announcement about the initiation of the project decision and the organization of all public consultations, and the targeted one can be applied complementary to the general information, at the decision of the public authority. The written request from interested parties for information on the decision-making process within the public authorities is set out in the form of a request, stating: the wish to receive information on the decision-making process of the authority and the initiation of public consultations, as an appropriate denomination of the project elaborated by the public authority and subject to public consultation, the name, surname of the citizen or the name, in the case of associations established by the law or other interested parties, the preferred way of receiving information (postal address, e-mail). The general information is made by placing the information on the official website of the public authority, displaying it at the headquarters in a space accessible to the public, disseminating, as the case may be, a press release in the central or local media. Targeted information is provided by sending information on the decision-making process by e-mail or sending letters to interested parties or the one indicated by the applicant. The information about the initiation of 
the elaboration of the decision is made through an announcement drafted and disseminated under the conditions of Law no. 239-XVI of November 13, 2008, regarding the transparency in the decision-making process.

In order to facilitate the access of interested parties to the information on the process of elaboration and adoption of decisions by the public authority, compartments are created on its official website in order to be dedicated to decision-making transparency, where information is placed on: internal rules on information procedures, consultation and participation in the process of drafting and making decisions; the name and contact information of the coordinator of the public consultation process in the decision-making process within the public authority; the annual (quarterly) programs for the elaboration of the project normative acts, with the indication of the project decisions to be submitted to public consultation; the announcements regarding the initiation of the elaboration of the decision; announcements regarding the organization of the public consultation; project decisions and related materials, as well as decisions taken; results of public consultation (minutes of public consultative meetings, summary of recommendations); the annual report of the public authority on the transparency of the decision-making process; other information.

The public authorities are obliged to make public the annual activity programs (plans), the annual (quarterly) programs for the elaboration of the project normative acts, elaborated according to Law no. 317-XV of July 18, 2003, on the normative acts of the Government and other authorities of the central and local public administration [4], indicating the project decisions to be submitted to public consultation.

Another relevant aspect to consider is the announcement of the public consultation. The information on the organization of public consultations on a project decision is drafted in the form of a notice which includes: the argumentation of the need to adopt the decision; ad placement date; the deadline for submitting recommendations; how stakeholders can access the project decision; the manner of public consultations; how stakeholders can present or send recommendations; the name and contact information (telephone number, e-mail address, postal address) of the persons responsible for receiving and examining the recommendations relating to the project decision to be consulted. The announcement is accompanied by the project decision and its related materials (informative notes and, as the case may be, analytical studies, regulatory impact analysis documents, other materials that formed the basis for the project decision, etc.). The notice of organization of the public consultation shall be made public at least 15 working days before the initiation of the procedure for drawing up the final version of the project decision. The announcement is made public through general information to the general public and targeted information to stakeholders.

The argumentation of the need to elaborate and approve the draft decision is formulated in a concise, explicit, and accessible language to the general public, with the explanation of the specialized terms. The argumentation refers to the purpose 
pursued by the project decision, its impact, the compatibility of the project with the legislation in force, the corresponding provisions of the community legislation, and the international treaties to which the Republic of Moldova is a party, other relevant details. Project decisions on which the public consultation procedure has been initiated shall be made available to interested parties.

The third relevant aspect is the information on the results of the public consultation. The results of the consultation (minutes, summary of recommendations), after their approval by the management of the public authority, are made public by general information until the adoption of the respective decision [5]. The decisions adopted by the public authorities, subject to public consultation, are made public, according to Law no. 982-XIV of May 11, 2000, on access to information.

In order to not violate their right to information, every citizen should know that information providers have certain obligations that they must comply with. Thus, the information provider, in accordance with its competences, is obliged: to ensure the active, correct and timely informing of the citizens on the issues of public interest and on the issues of personal interest; to guarantee free access to information; to respect the limitations of the access to information, provided by the legislation, in order to protect the confidential information, the private life of the person and the national security; to comply with the deadlines for providing the information, provided by law; to publish its own acts adopted in accordance with the law; to keep, within the terms established by law, their own acts, the acts of the institutions, whose successors they are, the acts that establish their legal status; to ensure the protection of the information at its disposal from unauthorized access, destruction or modification; to keep the information, the documents at its disposal, in an updated form; to urgently disseminate to the general public the information that has become known to them in their own activity, if this information: can prevent or reduce the danger to human life and health; may prevent or reduce the danger of damage of any kind; it can stop the spread of untrue information or reduce the negative consequences of its dissemination; carries a special social importance, to ensure the provision of data from state registers through the interoperability platform.

In order to guarantee free access to official information, the information provider will provide a space arranged for documentation, accessible to applicants; will appoint and train the officials responsible for carrying out the procedures for providing official information; will elaborate in accordance with the present law, regulations regarding the rights and obligations of the officials in the process of providing the official documents, information; will provide the necessary assistance and support to applicants for searching and identifying information; will ensure effective access to the registers of information providers, which will be completed in accordance with the legislation on registers; will ensure effective access, through the interoperability platform, to the registers of information providers, which will be completed in accordance with the legislation on registers; will hold its meetings in public, in accordance with the law; In order to facilitate free access to information, 
the information provider will publish or otherwise make generally and directly accessible to the population the information containing: the description of the structure of the institution and its address; description of the functions, directions and forms of activity of the institution; description of the subdivisions with their competencies, their work schedule, indicating the days and hours of hearing of the officials responsible for providing information, official documents; final decisions on the main issues examined.

In order to ensure the transparency of the institutions' activity, to make the access to information more efficient, to create the conditions for searching, the operative identification of documents and information, public authorities, public institutions will publish, at least once a year, guidance containing lists of provisions, decisions, other Official documents issued by that institution and the areas in which it may provide information shall make available to the media representatives official data on its activity, including areas in which it may provide information. The information provider will use, if necessary, other forms of active information of citizens and the media [6].

The involvement of citizens in the decision-making process at local level is regulated in the Law on local public administration, which expressly provides that in matters of special importance for administrative-territorial unity, the population can be consulted by local referendum, organized under the Electoral Code. In matters of local interest that concern a part of the population of the administrative-territorial unit, various forms of consultations, public hearings and conversations can be organized with this part, following the law. The project decisions of the local council are publicly consulted by the law, in compliance with the procedures established by each representative and deliberative authority of the population of the first or second level administrative-territorial unit, as the case may be. At the same time, local meetings must be public. Anyone interested can attend its meetings. Citizens, associations established by the law and other interested parties have the right: to participate following the law, at any stage of the decision-making process; to have access to the information regarding the locality's budget and the way of using the budgetary resources, to the project decisions and the agenda of the meetings of the local council and the mayor's office; to propose the initiation of the elaboration and adoption of decisions; to present to the local public authorities recommendations, in their name or on behalf of groups of inhabitants of the respective communities, regarding various project decisions to be debated. Local public authorities and civil servants of the respective administrative-territorial units are obliged to take the necessary measures to ensure the effective possibilities of participation of citizens, associations established by the law and other stakeholders in the decision-making process, including through: adequate information and in due time on the topics debated by the local council; receiving and examining, in due time, all the recommendations, notifications, letters, addressed by the citizens to their representative authorities, when elaborating the draft decisions or the activity programs; promoting a policy of 
communication and dialogue with citizens; publishing programs, strategies, agenda of meetings on various information media [7, pp. 35-36].

M. Platon mentioned that citizen participation should not be reduced to the simple expression of electoral options, the democratic designation of elected officials and local government bodies, but should create a continuous partnership between public servants and public, between public service providers and their users, improving management in local public administration, expressly involves the establishment and improvement of mechanisms for public consultation and participation. However, successful participation does not appear spontaneously, especially when the partners involved do not have the experience of this kind of civic action. It is important to have some form of encouragement, training, and support for participation attempts to be successful. A participatory training infrastructure needs to be organized, ranging from the simplest to decision-making issues [8, p.60-61]. In this sense, S. Cobăneanu emphasizes, local councils must find the optimal solutions for the efficient communication with the citizens, solve local problems, find the most successful development model for the respective area $[9$, p.9]. The role of local public authorities is related to solving local public problems according to the needs, requirements expressed by the communities, being in a close relationship with the specifics of the administrative-territorial unit. Exercising their attributions, the local public administration authorities have autonomy guaranteed by the Constitution, international treaties, by the European Charter of Local Autonomy to which the Republic of Moldova is a party, as well as by other normative acts. On this basis, it is expressly stated that the purpose of local public administration is to solve and manage through its autonomous authorities in its own name and under its responsibility a very important part of public affairs in the interest of local authorities [10].

In the Republic of Moldova, the tendency of community involvement is increasing because it is trying to identify the major problems seen through the prism of citizens and finding solutions in this regard. Thus, we capture a transforming socio-political framework of the changing society, accompanied by evolutionary, complex, and multivalent factors as major social significance and resonance for the common good, but also for the good of each citizen. Such factors are mainly related to sociopolitical modernization and democratization (without which transparency would be impossible to achieve), considered as decisive factors in achieving the strategic objectives of the changing society. The factors in question, perceived in their entire value area of manifestation and influence, depending on the political order in society, which, in turn, is largely dependent, as noted by Samuel P. Huntington, quoted by V. Saca, "the development of political institutions and the mobilization of new social forces in politics" [11, p.55]. What needs to be understood in this context is that public administration authorities must perceive any change as a necessity, and political forces, which should not, according to the legal provisions, be directly involved in the activity of public administration nevertheless show an 
attitude. benevolent and open to collaboration with citizens and civil society. The interest of the citizen should not be of interest to the political class only before the elections but throughout the term of office. Awkward questions should be asked at all times in order to take action. A transparent decision-making process will facilitate the solution of the fundamental problems of society, and the citizen must be the basic subject for which decisions are made. Civil servants must perceive the citizen in terms of the following categories: the citizen is the most important person for the civil servant - by phone, by mail, or when a citizen comes in person; the citizen does not depend on the local authorities - the local authorities depend on the citizen; the citizen is not the one who interrupts work - but it is the very purpose of this work; the citizen is not outside the activity of the local public administration - but a part of it; the citizen is the person who communicates their wishes to the local public administration. The purpose of local public administration is to treat them in a way that benefits both parties. In the same context, we mention that the citizen pays local taxes and fees, pays for services. The citizen has the right to buy quality services and to buy those services he needs, and he can do this through direct or indirect participation (through the officials elected by them) in the decision-making process. The normative framework of the Republic of Moldova ensures the right of citizens to participate in the decision-making process, but at the same time citizens also have responsibilities: to observe what the local administration does and for what purpose; be prepared to make a contribution when the administration plans to do something that may affect their interests; to approach the representatives of the administration with a positive attitude; show interest in understanding issues, including restrictions on what the administration can do; to express their interests and ideas clearly and completely; Inappropriate situations, try to collaborate constructively with local government officials to find and implement solutions that are satisfactory to both parties [12, p.23-24]. One thing is certain, at the moment, during the COVID-19 pandemic, it is much more complicated to participate in the decision-making process. The restrictions imposed can create a barrier between the citizen and civil servants, so that the citizen feels limited in actions and rights. Most decisions can be made unexpectedly, without public consultation, or with minimal access, which creates major communication problems in the community-public administration relationship. Delaying decisions as a result of restrictions may have a negative impact over time. The citizen feels barriers because faces reality, which is different from before, namely: the citizen cannot participate in Council meetings, solving citizens' problems (considered by minor civil servants) are postponed, reduced civil servant activity can create impediments in time in solving urgent problems, the fear of people to relate decreases performance, tightening the bureaucratic system due to insecurity for the future. All these are the consequences that appear due to this pandemic, an unforeseen situation both in the Republic of Moldova and around the world. Citizens' confidence in the governing forces was quite weak, now it has diminished even more, and the authorities need to work hard to regain the full trust of citizens. 
The leaders of the Republic of Moldova must double their efforts to fight corruption and to ensure impartial justice for all citizens. Real justice reform requires a long-term vision, extensive and ongoing consultation with civil society and political parties, and a constant commitment to strengthening the rule of law. The economic recovery of the Republic of Moldova, which is already a difficult task, will be even more difficult if corruption continues to flourish. Corruption facilitates external interference in the justice and financial systems, discourages foreign investment and entrepreneurship, slows down the creation of new jobs, and forces talented young people to look for opportunities elsewhere. The negative effects of corruption will only be exacerbated by the current economic crisis [13]. Transparency must also be ubiquitous and not manipulated by controversial opinions. The misinformation was promoted on several televisions, risking provoking panic. In the conditions of a global pandemic, of the fragile situation of the health system, of the large number of citizens of the Republic of Moldova returning from the areas affected by COVID-19, a maximum responsibility of the whole society and, first of all, of the authorities, is necessary through correct information and impartiality. During this period, it is increasingly possible to manipulate information to the detriment of the ruling political class, and transparency remains only a notion in the legislation because each political class wants to express its opinion in its favor, often excluding some realities. Although the digital age has opened up opportunities for the formation and development of critical thinking of the citizens, public opinion can often be misled by untrue statements or some hidden truth. However, an active and informed citizen, who knows their rights, is informed from various sources so as not to be misled. In the reality of the Republic of Moldova, where a large percentage of the media operates on political criteria, it is much more complicated to find out where there is truth, transparency and where there is interest. There is still a lot of work to be done in this regard. In a democratic state, where the law and human rights are respected, the interest of the citizen is the goal of public administration authorities. Regardless of occupational status, position in society, or political views, all are equal in front of the law and have the right to request quality services and be provided promptly $[15$, p.97], even if it is a pandemic. The crisis must not affect the interest of the citizen, or the civil servant should not hide under these pretexts. Decisions taken during the pandemic period must not diminish the effectiveness of the services provided to the citizen. Even if the effects of the pandemic are often unforeseen, we must act rationally and not to the detriment of the citizen.

According to the SIGMA Country Report, the legislation on access to information of public interest is in force, but it does not cover the composition of public information that should be proactively disclosed by the administration, the responsibility for monitoring the implementation of the law has not been assigned to any institution. Therefore, there are no statistics on this issue, nor is there any proactive disclosure of public information or public awareness of the right of access to information. Ensuring 
transparency in the activity of public administration has not become a rule for the authorities to follow. Thus, the web pages of the central public authorities are not sufficiently updated. In particular, a number of mandatory information is often not published on the web, in particular: planned and executed budgets; the results of public procurement; anti-corruption activities; the results of the controls carried out by the authorities; there is no single approach to the web page interface, searching for information is difficult. Moreover, there are no law setting requirements for the web pages of the autonomous central public authorities; the study on the main issues and needs in the field, including proposals to amend the regulatory framework, has not been developed; the mechanism for permanent monitoring of compliance with the provisions of normative acts has not been established. The obligation to establish this mechanism occurs with the adoption of the Law on normative acts no. 100 of 22.12.2017 [16]. The law regulates the categories and hierarchy of normative acts, the stages, and rules of project elaboration, the requirements for the structure and content of normative acts, as well as the rules for monitoring the implementation of the provisions of normative acts. According to art. 75 of the cited law, the monitoring of the normative acts will be carried out in order to evaluate the degree of their application and execution, to identify the unforeseen or negative consequences, as well as to elaborate the recommendations to remedy the negative consequences. The monitoring of the implementation of the provisions of the normative act will be performed by the responsible institution at the latest after 2 years from the entry into force of the act. The mechanism for monitoring the implementation of normative acts will be established by the Government; changes in the regulatory framework, including for the establishment of disciplinary liability of heads of public authorities have not been made [17].

Transparency in the activity of public administration is a multidimensional concept, which has provoked controversial discussions among scholars, analysts, and politicians in various contemporary societies. This is not only equivalent to the right of citizens to have access to information, even if it is the most important and most open side to various interpretations. In addition to the right to be informed, a fully transparent administration implies the recognition and respect of the citizen's rights to understand the administrative process, the right to make their own opinion known, and the right to expose the opinion of others to objective and reasoned criticism. The interference of these two rights results in three distinct areas of a transparent public administration, namely: information, control, and participation of citizens in the decision-making process. The right of citizens to be informed and the obligation of the authorities to inform are enshrined in constitutional norms that oblige public administration authorities to ensure the correct informing of the citizens on public affairs and on matters of personal interest. The development and correlation of the constitutional provisions with the other legislative provisions lead us to the conclusion that the right of citizens to have access to any information of public interest cannot be restricted. The public administration authorities, within 
their competencies, are obliged to ensure the correct information of the citizens on the public affairs, a provision that also refers to the mass media. The principle of citizen consultation, through the forms provided by law, when adopting decisions with a special impact on local authorities, expresses the idea of participatory democracy [18]. This idea, taken from the community states that already have experience in this regard, is trying to be promoted more and more often in the Republic of Moldova. Participatory democracy has become an integral part of the European model of society. The Lisbon Treaty enshrines the complementarity between representative democracy and participatory democracy, mentioned in art. 10, respectively 11 . In addition, art. 10 paras. (3) gives citizens the right to participate in the democratic life of the European Union and also provides that decisions are taken as openly and as closely as possible to the citizen, a reference to the requirement of respect for the principle of subsidiarity. Thus, participation becomes a citizen's right, and subsidiarity becomes a pillar of participatory democracy. Art. 11 stipulates that the institutions grant to the citizens and the representative associations, by appropriate means, the possibility to make known their opinions and to exchange opinions in public, in all fields of action of the European Union. The European Union institutions maintain an open, transparent, and constant dialogue with representative associations and civil society. In order to ensure the coherence and transparency of the European Union's actions, the European Commission shall consult widely with the stakeholders. At the initiative of at least one million citizens of the European Union, nationals of a significant number of Member States, the European Commission may be invited to submit, within the limits of its remit, an appropriate proposal on matters in which these citizens consider it necessary of the European Union, with a view to the application of the Treaties. The procedures and conditions necessary for the presentation of such an initiative are established in accordance with art. 24 first paragraph of the Treaty on the Functioning of the European Union [19].

In general, public decision-making is a reflection of the system of government. In an autocracy, public decisions are made by one or more decision-makers. In a democracy, decisions are made directly by the citizens (direct democracy) or by their elected representatives (representative democracy). In modern systems, elected representatives of citizens obviously have the right to make public decisions. They can make this decision on their own, based on discussions between themselves or between them and experts, or between them, experts and the public. The involvement of citizens or interest groups in decision-making makes democracy participatory. At the same time, it is important to be aware that public involvement does not mean that the decision is made by the public, but it does mean that the public's opinions and suggestions regarding a particular public decision are taken into account by the administration. Participatory democracy therefore cannot be confused with direct democracy, as the coordination of the promoted policy does not imply the transmission of the prerogatives of the citizens, delegated to the 
elected persons. By attracting people to participate, the representatives of the power assume the obligation to elaborate solutions in accordance with the opinions and wishes of the citizens. They usually reserve the role of arbitrator in the decisionmaking process, except for decisions taken by referendum. Thus, participation is a distinct goal, but it is important in itself, as the right to participate in social processes is de facto recognized by the international community as a fundamental human right. Participation is also important because it is a tool with which other important goals can be achieved. Specifically, participation contributes to the development of democracy, to the consolidation of social capital, to the increase of efficiency, equality, and social equity.

The right of citizens to initiate bills or hold referendums, to be consulted on various draft decisions are elements of "participatory democracy", which thus compensates for certain shortcomings of "representative democracy". In other words, "participatory democracy" is the continuous relationship between the elected and the voter, between the civil servant and the citizen. It represents practically the "dialogue with the citizen". Ideally, all the members of a community should be able to participate in joint decision-making. Summarizing the essence and significance of participatory democracy, we mention that it necessarily involves the following important moments: in a participatory democracy, public administration must be with and for the people; the right of citizens to be informed about the activity of the authorities, but also the right to participate in the decisionmaking process; good governance must become a partnership between citizens and elected officials, in whom they have invested their trust; trust is manifested through honesty, transparency on the part of the elected, the opportunity offered to citizens to have an important role both in the governance process and in their daily work; the concept of participatory democracy is the essence of people's rights to be consulted, thus, citizens, in general, legally established associations, other stakeholders have the right to participate and get involved in the decision-making process of public authorities. At the same time, it is necessary to be aware of the truth that democracy itself does not guarantee anything. Instead, it offers the possibility of success, but also the risk of failure. Democracy is therefore both a promise and a demand. It is the promise that free people, by cooperating, can govern themselves in a way that will satisfy their aspirations for personal freedom, economic opportunity, and social justice. It is, at the same time, a request, because the success of democracy depends on the citizens of that society and on no one else [7, pp. 35-36].

The pandemic period put new obstacles in the way of governance related to participatory democracy, the possibility of engaging the citizen in monitoring the act of governing, and in general in carrying out the reforms that were planned. The declaration of a state of emergency was the beginning of a new and complicated period, both for the Republic of Moldova and for the whole world. However, in the Report on the monitoring of the COVID-19 crisis in the Republic of Moldova, May-September 2020, the Association for Participatory Democracy ADEPT 
with the support of the Good Governance Department of the Soros Foundation Moldova, in terms of informing the public came with the following findings. The campaign to inform citizens about what a new type of coronavirus is and how to protect yourself against COVID-19 was launched on 24.02.2020, following the convening of the first meeting of the Working Group of Communicators at the national level, established by the Ministry of Health, Labor and Social Protection, which discussed the National Plan for Communicating Public Health Emergency Risks. Representatives of Parliament, the Presidency, the Government, the Ministry of Health, Labor and Social Protection, as well as other public administration authorities and representatives of international organizations, were included in the Working Group of National Communicators. Consequently, the Working Group of Communicators at the national level established the communication actions, which were summarized in: the online distribution of information materials on the official pages of important state institutions; creating banners on the official website of the Ministry of Health, Labor and Social Protection with all concentrated information; distribution of leaflets at land and air border crossing points; sending informative messages to customers from the Moldcell, Orange and Unite mobile networks; the dissemination on the LED screens of the means of public transport of the info-graphics and subsequently the placement of the informative posters on the panels in the city, with the support of the local authorities; the development of additional materials for distribution at border crossings, as well as the development of video spots with the support of the World Health Organization, containing clear instructions on the rules to be followed for the prevention of COVID-19 infection, etc. [20]. Citizens were fully informed about all coronavirus prevention measures. However, the problems were growing, and the leadership was facing more and more barriers that had to be solved with the utmost seriousness and caution. There have also been cases where certain decisions have been delayed due to the pandemic in favor of interest groups. The report also mentions that the efficiency of crisis management has suffered due to the involvement of the political factor to the detriment of the professional one in the process of adopting and implementing measures to prevent and combat the spread of COVID-19 infection. The discussion and adoption of decisions on multiple platforms, with the participation of representatives of the country's top leadership, was followed by the formalization of those decisions by the competent institutions. This has considerably diminished the share of the voice of medical professionals in the decision-making process. In general, it should be noted that there was no clear and transparent decisionmaking mechanism. Consequently, a number of adverse effects have emerged, with negative impacts, not only on the evolution of the epidemiological condition but also on respect for human rights [20].

If the citizens were informed daily about the measures taken by the authorities in stopping the Covid-19 virus, then less was known about the rest of the decisions. Firstly, the authorities were primarily concerned with the situations created by the 
pandemic, and secondly, the citizens themselves were less interested in what was happening in addition to the situation created worldwide. However, some decisions were made, regardless of whether the citizens were involved or not. According to the law, public authorities must use all possible tools to ensure transparency and access to data of public interest. As one of the tools used by public authorities is the information panel, this method was not relevant in the context in which citizens were prohibited by law from leaving the house unfounded. A much more modern and effective method in the digital age is the tools for disseminating information of public interest, namely web portals of public administration authorities and social networks, where the public authority must place relevant information about its activity even during the pandemics. However, such information has been lacking on many government platforms.

COVID-19 has evolved rapidly into a global emergency. The governments of many states have reacted to the pandemic as a national security issue. For example, some Council of Europe member states has imposed restrictions, with a temporary derogation from obligations under human rights treaties, such as the European Convention on Human Rights. The Republic of Moldova was no exception, being among the top ten countries that announced a possible non-compliance with the provisions of the Convention for reasons of national security. In accordance with art. 15 of the Convention, derogation is allowed "in case of war or other public danger that threatens the life of the nation" to the strict extent required by the situation. This provision allows states to exercise their national powers in a state of emergency, which could result in a deviation from the protection of fundamental rights, including freedom of opinion and expression. However, the need to defend the nation in a crisis must be weighed against an equally vital need - that of protecting fundamental rights. According to the joint statement of the Office of the UN High Commissioner for Human Rights (OHCHR), the Organization for Security and Cooperation in Europe (OSCE), and the Inter-American Commission on Human Rights (IACHR): “The right to freedom of expression, which includes the right to seek, receive and disseminate information and ideas of all kinds... can only be subject to "restricted restrictions" during the health crisis. To ensure these freedoms, this declaration urges countries to ensure the correctness, accessibility, and transparency of pandemic information for citizens and journalists, as well as to eliminate the real risks of misinformation in accordance with strict standards of proportionality and necessity. The OCHCR also warns that emergency powers should be used to achieve legitimate public health goals, not to suppress dissent or silence human rights defenders or journalists. Moreover, the European Court of Human Rights (ECHR) imposes strict requirements for the countries that invoke art. 15 of the European Convention on Human Rights, including the obligation of national authorities to justify in a transparent manner the relevance, adequacy, and proportionality of government interference with fundamental human rights with the legitimate aims pursued". Specifically, in order to demonstrate the proportionality and necessity of 
the measures, the State must demonstrate the adequacy and narrow application of a restriction in order for it to perform its protective function; demonstrate that the measure is the least intrusive instrument compared to other protective measures; to ensure the cessation of the effect of the restrictions imposed while reducing and eliminating the danger. The first decisive step that determined the need to identify that balance between national security and human rights in the Republic of Moldova was taken with the declaration by the Government of the country on March 16, 2020, of the state of emergency for a period of 60 days. As a result of the establishment of the state of emergency regime, the Commission for Exceptional Situations convened by the Prime Minister, composed of members of the Cabinet of Ministers, was empowered to adopt extra-legal measures to combat the danger to public health, including coordination of mass media activity in informing the population about the causes and proportions of the exceptional situation, as well as other broad restrictions. These measures were taken in accordance with Law no. 212 on the regime of the state of emergency, siege, and war [21], which gives the Government the right to apply temporary measures of a political, economic, and social nature to ensure public order in exceptional situations.

Some post-Soviet states have taken emergency measures against the spread of the pandemic that directly affects media freedom. Among the countries that have adopted the most severe measures are Belarus and Russia. The governments of both countries have been accused of imposing severe restrictions on access to information and the use of police forces to limit the media coverage of the spread of the virus, which is at odds with government messages. Access to information of public interest was among the first targets of the restrictions imposed in the Republic of Moldova in connection with the pandemic. On March 18, 2020, the Commission for Exceptional Situations extended the deadline for responding to requests for information from journalists for state institutions from 15 to 45 days, without any official explanation of the reasons behind this decision, other than invoking the mandate of the Law no.212 to support public order. Unofficially, government spokesmen told reporters that their employees were too busy coping with the pandemic to respond to requests for information. Problematic restrictions on the right of access to information have always existed in the Republic of Moldova since independence, and the new provisions adopted in connection with the state of emergency further aggravate the existing problems. Extending the deadline for responding to requests for information, in addition to all the others mentioned above, compromises the ability of journalists in the Republic of Moldova to provide citizens with vital and up-to-date information. Moreover, the decision to triple the deadline for examining requests for information contradicts the standards of proportionality and necessity, which the country must comply with in accordance with international law. Informing the citizens of the Republic of Moldova in a situation of a global health emergency is of major importance and must be a clear priority of the Government during the state of emergency. By refusing to come up with a transparent national security justification for the application of such a 
measure, the Commission's decision is unnecessary but also causes disproportionate harm to the country's citizens [22]. Thus, it is clear that the principle of transparency has been prejudicially infringed throughout the exceptional situation and beyond. The COVID-19 pandemic period is characterized by a lack of transparency and uncertainty. It is difficult for citizens to understand what is really going on in the socio-economic and political life of the country because many facts are not made public. Citizens are grouped into categories: those who believe and those who do not believe in the existence of the virus. It is a stressful period with medium and longterm consequences.

The European Union is committed to protecting societies, citizens, and freedoms from hybrid threats, including misinformation, as outlined in the Strategic Agenda 2019-2024. The aim is to step up cooperation in identifying, preventing, and counteracting attacks while increasing resilience to these threats. In the context of the intensification of disinformation activities related to the COVID-19 pandemic, the institutions of the European Union have acted to raise awareness of the dangers of misinformation and have promoted the use of reliable sources. In addition, the European Union has encouraged online platforms to help combat false news and other attempts to spread misinformation by eliminating illegal or false content. The European Commission and the High Representative of the Union for Foreign Affairs and Security Policy issued a joint communication on 10 June 2020 entitled "Combating misinformation about COVID-19 - Ensuring fair information", proposing concrete actions to increase the Union's resilience against the challenge of misinformation. These include increasing European Union support for fact-checkers and researchers, strengthening the European Union's strategic communication capabilities, and strengthening cooperation with international partners, while guaranteeing freedom of expression and pluralism [23].

In the Republic of Moldova, skepticism about freedom of expression and truthfulness of information is still pervasive. Citizens are confused and often undecided. Thus, in order for the citizen to feel safe, they must be properly informed and able to act in order to meet their needs in the country where all their rights should be respected, regardless of the situations created. The authorities must show interest in the citizen and avoid personal interests. The unforeseen situation, which has affected the whole world through the spread of the COVID-19 virus, has made it more difficult for public authorities to carry out tasks, but it should not prevent citizens from being informed correctly and in a timely manner about all decisions taken. Thus, we come with the following recommendations: the active involvement of civil society in monitoring the decisions taken by the public authorities; involving citizens in the decision-making process and complaining about cases where their rights are being violated; effective collaboration between the media, civil society and public authorities; engaging every honest civil servant in the public interest; displaying all information that should, in accordance with the law, be brought to the attention of the general public. 


\section{Transparency of the decision-making process during the coronavirus pandemic}

\section{BIBLIOGRAPHICAL REFERENCES}

1. Constituția Republicii Moldova. http://www.parlament.md/CadrulLegal/Constitution/ tabid/151/language/ ro-RO/Default.aspx. (vizitat 02.11.2020).

2. Ciobanu I., Latco A. Asigurarea transparenței procesului decizional prin intermediul tehnologiilor informaționale. Studiul de caz în municipiul Bălți. http://dspace.aap.gov.md /bitstream/handle/123456789/1426/tpap_2020-336-339.pdf?sequence=1\&isAllowed=y. (vizitat 02.11.2020).

3. Legea $\mathrm{nr} .239$ din 13.11.2008 privind transparența în procesul decizional. http://lex.justice.md/index.php? action=view\&view=additional\&id=329849\&lang=1. (vizitat 19.10.2020).

4. Legea nr. 317-XV din 18 iulie 2003 privind actele normative ale Guvernului şi ale altor

autorităţi ale administraţiei publice centrale şi locale. https://www.legis.md/ cautare /getResults?doc_ id=28260\&lang=ro. (vizitat 19.10.2020).

5. Hotărârea Nr. 96 din 16.02.2010 cu privire la acţiunile de implementare a Legii nr. 239-XVI din 13 noiembrie 2008 privind transparenţa în procesul decizional. https://www.legis.md/cautare/getResults?doc_ id=22618\&lang=ro. (vizitat 20.10.2020).

6. Legea nr. 982 din 15.05 .2000 privind accesul la informație. https://www.legis.md/ cautare/getResults?doc_ id=108552\&lang=ro. (vizitat 22.10.2020).

7. Pînzaru. T. Asigurarea juridică a implicării cetățeanului în procesul decizional al autorităților de guvernare și reprezentative. Teză de doctor în drept. http://www.cnaa.md/files/theses/2015/21918/pinzaru_tudor_ thesis.pdf. (vizitat 25.10. 2020).

8. Platon M. Serviciul public în Republica Moldova. Chișinău: AAP, 1997. 224 p

9. Cobăneanu S. Administraţia publică: aspecte practico-ştiinţifice, probleme şi perspective. În: Administraţia publică: aspecte practico-ştiinţifice, probleme şi perspective. Conferinţă ştiinţifico-practică. Chişinău: CEP USM, 2004, p. 5-13.

10. Ceacîr I. Cultura organizațională în contextual modernizării administrației publice locale: abordare politologică. Teza de doctor în științe politice. http://www.cnaa.md/files/ theses/2018/53945/irina_ceacir_thesis. pdf. (vizitat 02.11.2020).

11. Saca V. Raportul dintre democratizare și modernizare în condițiile societății în schimbare. În: Republica Moldova în contextul necesităților de modernizare. Chișinău, 2018, p.55-83.

12. Șaptefrați T. Buna guvernare prin prisma participării cetățenilor la procesul decizional. În: Administrarea publică, 2020, nr.1, p. 22-31.

13. Chiar și în timpul pandemiei trebuie să fim atenți și la sănătatea democrației Republicii Moldova. https:// md.usembassy.gov/ro/chiar-si-in-timpul-pandemiei-trebuie-sa-fim-atenti -si-la-sanatatea-democratiei-republicii-moldova/. (vizitat 22.09.2020).

14. Apel COVID-19 în Republica Moldova: Vrem adevăr și transparență. https://cpr.md/ 2020/03/12/apel-covid-19-in-r-moldova-vrem-adevar-si-transparenta/. (vizitat 22.09. 2020).

15. Ceacîr I. Meritocrația și rolul ei în funcția publică. În: Revista de Filosofie, Sociologie și Științe Politice, 2019, nr.2 (180). p. 97-112.

16. Legea cu privire la actele normative $\mathrm{nr} .100 \mathrm{din} 22.12 .2017$. https://www.legis.md/cautare/getResults?doc id=105607\&lang=ro. (vizitat 22.09. 2020).

17. Palihovici S., Palihovici L. Responsabilitatea și transparența în administrația publică: element cheie în procesul de reformare a administrației publice. https://ibn.idsi.md/sites/ default/files/imag_file/59-66_10. pdf. (vizitat 04.11.2020).

18. Fotescu V. Participarea cetățenilor la procesul de administrare publică. https://ibn.idsi.md /sites/default/ files/imag_file/173_179_Participarea\%20cetatenilor\%20la\%20procesul\%20de\%20administrare\% 20 publica.pdf . (vizitat 19.09.2020).

19. Democrația participativă în 5 puncte. https://www.eesc.europa.eu/resources/docs/pd-in-5-points-ro.pdf. (vizitat 22.09.2020).

20. Raportul privind monitorizarea crizei COVID-19 în Republica Moldova. http://www.e-democracy.md/files/ raport-covid-19-moldova.pdf. (vizitat 23.10.2020).

21. Legea nr. 212 privind regimul stării de urgenţă. https://www.legis.md/cautare /getResults?doc_ id=27024\&lang=ro. (vizitat 23.10.2020).

22. Pandemia COVID-19: Lecții pentru libertatea mass-media în Republica Moldova. https:// freedomhouse. org/sites/default/files/2020-06/Balan\%20and\%20Stegniy_FINAL-RO_0. pdf. (vizitat 23.10.2020).

23. COVID-19: răspunsul UE în domeniul sănătății publice. https://www.consilium.europa.eu/ro/policies/coronavirus/covid-19-public-health/. (vizitat 12.10.2020). 